\section{YEARBOOK}

of ANTITRUST

and REGULATORY

STUDIES

www.yars.wz.uw.edu.pl
Peer-reviewed scientific periodical, focusing on legal and economics issues of antitrust and regulation. Creative Commons Attribution-No Derivative Works 3.0 Poland License

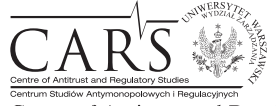

Centre of Antitrust and Regulatory Studies,

University of Warsaw, Faculty of Management www.wZ.uw.edu.pl

\title{
Liberalization without a Regulator. The Rail Freight Transport Market in Poland in the Years 1996-2009
}

\author{
by
}

Marcin Król*

\section{CONTENTS}

I. Introduction

II. Market liberalization process (1997-2009)

III. Troubles with access to railway infrastructure

IV. Railway market regulator in Poland

V. Conclusions

\section{Abstract}

This article focuses on the liberalization process of the railway freight transport market in Poland between 1997 and 2009. It shows that the increase in traffic and the fall in prices that occurred in this period took place not because of 'effective regulation' but despite its absence. This can indicate that introducing competition in railway freight transport could be profitable where there is significant demand for bulk and containers freight services and the railway infrastructure is well-developed.

\section{Résumé}

Larticle se concentre sur le processus de libéralisation du marche de transport ferroviaire de fret en Pologne dans les années 1997-2009. Il montre que l'augmentation du trafic et la baisse des prix dans cette période, n'ont pas eu lieu à cause de la 'régulation efficace', mais malgré son absence. Cela peut indiquer que l'introduction de la concurrence dans le transport ferroviaire de fret pourra être profitable s'il y a de la demande pour les services du trafic en vrac et par conteneur et si l'infrastructure ferroviaire est bien-developpée.

* Dr. Marcin Król, Collegium of World Economy, Warsaw School of Economics. 
Classifications and key words: railway transport; economic regulation; market liberalization.

\section{Introduction}

The first part of the title of this article is a deliberate provocation. Half a century ago, G.J. Stigler and C. Friedland wrote in their classic article entitled 'What can regulators regulate? The case of electricity', that the mere existence of regulatory action does not mean 'effective regulation' but is only a sign of a 'desire to regulate'. What happens however if the regulator does not even have the 'desire to regulate'? It is worth looking in this context at the liberalization of rail freight transport in Poland. A railway transport regulator exists in Poland only in theory. A dynamic development of competition (resulting in the highest rate in the EU of market penetration by non-public freight railway undertakings), an increase in traffic and a decrease in prices has not taken place thanks to 'effective regulation' but despite its absence.

The subject matter of this paper is the liberalization of rail freight transport in Poland, rather than an analysis of the concept of 'effective regulation'. Thus, the conditions that must be met to realize the concept of 'effective regulation' will not be discuss in detail at this point. It is assumed that 'effective regulation' cannot occur in the initial period after the liberalization of previously monopolized railway markets without an 'efficient' way to ensure infrastructure access of new market players (infrastructure is an essential input for this industry). A commitment on the side of the regulator (the 'desire to regulate') is also necessary in the sense that the authority considers it appropriate to uphold the new rules of the game. These two issues will be the focus of the later parts of this article after the presentation of the market liberalization process of rail freight in Poland.

\section{Market liberalization process (1997-2009)}

The liberalization process of Polish rail freight was formally launched by the Railway Transport Act of $1997^{2}$ which introduced the concept of a 'licensed operator authorized to provide railway services' (i.e. a railway undertaking)

1 G. J. Stigler, C. Friedland, 'What can regulators regulate? The case of electricity' (1962) $\mathrm{V}$ The Journal of Law and Economics 1.

2 Act of 28 March 2003 on Railway Transport (consolidated text: Journal of Laws 2007 No. 16, item 94 as amended). 
and imposed a 'separate accounting' obligation for rail operations and rail infrastructure. In the years 1998-1999, 21 operators were granted freight concessions in Poland including the national incumbent - Polskie Koleje Państwowe (Polish State Railways; hereafter, PKP). In the same period, 7 companies received infrastructure management concessions - PKP as well as private undertakings owned mainly by Silesian mining companies.

The Act of 1997 was a step towards the implementation of acquis communitaire (Directive 91/440/EEC ${ }^{3}$ followed by Directives 95/18/EC ${ }^{4}$ and 95/19/EC ${ }^{5}$ necessary for Poland's accession to the EU. However, its liberal licensing provisions seemed to have also been designed as an instrument of political pressure on railway unions. The unions were opposed to the acceleration of the government's restructuring program of the former monopolist, which was being implemented for several years already, organizing particularly frequent and prolonged strikes in the second half of the 1990ties. The government wanted to show those of the railway sector that there could be an alternative to state-owned railways ${ }^{6}$.

It quickly became apparent however that the government did not see market liberalization as a remedy to the rail transport crisis of the 1990ties, clearly focusing on the economic recovery of PKP instead. The minister of transport responsible for the surveillance of the rail transport market failed to respond to complaints submitted by other operators concerning network access denials. Before 2002, the fees for the use of railway infrastructure were not under ministerial purview - they were approved by the PKP Board only. After much deliberation with the railway unions, Railway Act on the Commercialization, Restructuring and Privatization of PKP was finally agreed upon in 2000. Importantly, not only did the new law reform the incumbent, it also changed the liberal approach of its predecessor introducing far stricter licensing rules that obliged the railway undertakings that were already operating to apply for new licenses?

Consequently, until 2001, the activities of independent operators were generally limited to local freight services provided on the basis of the former industrial railways infrastructure. In 2002 the situation changed. Based on the

3 Council Directive 91/440/EEC of 29 July 1991 on the development of the Community's railways, OJ [1991] L 237/25.

4 Council Directive 95/18/EC of 19 June 1995 on the licensing of railway undertakings, OJ [1995] L 143/70.

5 Council Directive 95/19/EC of 19 June 1995 on the allocation of railway infrastructure capacity and the charging of infrastructure fees, OJ [1995] L 143/75.

${ }^{6}$ Such opinion is common in the Polish railway industry. See e.g. M. Grobelny, 'Pięć lat wolnego rynku kolejowych przewozów towarowych w Polsce' (2008) 9 Rynek Kolejowy.

7 The new law introduced, among other things, an obligation on railway operators to be equipped with rolling stock before applying for the license which was a major entry barrier. 
act of 2000, the PKP restructuring program had the incumbent divided into 24 smaller firms. One of these newly created companies was the infrastructure manager PKP Polskie Linie Kolejowe SA (Polish Rail Lines; hereafter, PLK). PLK remained part of the so-called PKP Group alongside other PKP-demerged operator companies such as the freight market incumbent PKP Cargo SA and local operating broad-gauge company LHS. The infrastructure manager gained however a separate Board while access rules and charges to be applied by PLK were to be approved by the Minister of Transport.

The first publication of the network statement and access charges by PLK took place on 1 April 2002. This date is often regarded as the actual beginning of the development of a free market for rail freight in Poland. Since 2002, the volume of operations of undertakings other than PKP has been gradually growing stimulated by the Polish economy entering into a phase of dynamic growth. This positive economic climate was also the reason to stop the volume decrease of PKP's operations that took place in earlier years. However, PKP Cargo was not able to take advantage of Poland's economic growth to generate an increase in its traffic volume, which shows weakness of this company. As illustrated by Figure 1, the entire increase in the total rail freight transport in Poland, which took place before the global crisis in 2008, can be attributed to the activities of new market entrants.

Over the next few years however, most of their activities had a purely regional nature focusing on 'internal' freight services provided to industrialized areas of the southern part of Poland. An analysis of the traffic data representing the activities of nearly all private operators in that period indicates a significant

Figure 1. Increase in rail freight transport volume (mil. tonnes) - total vs. PKP Group

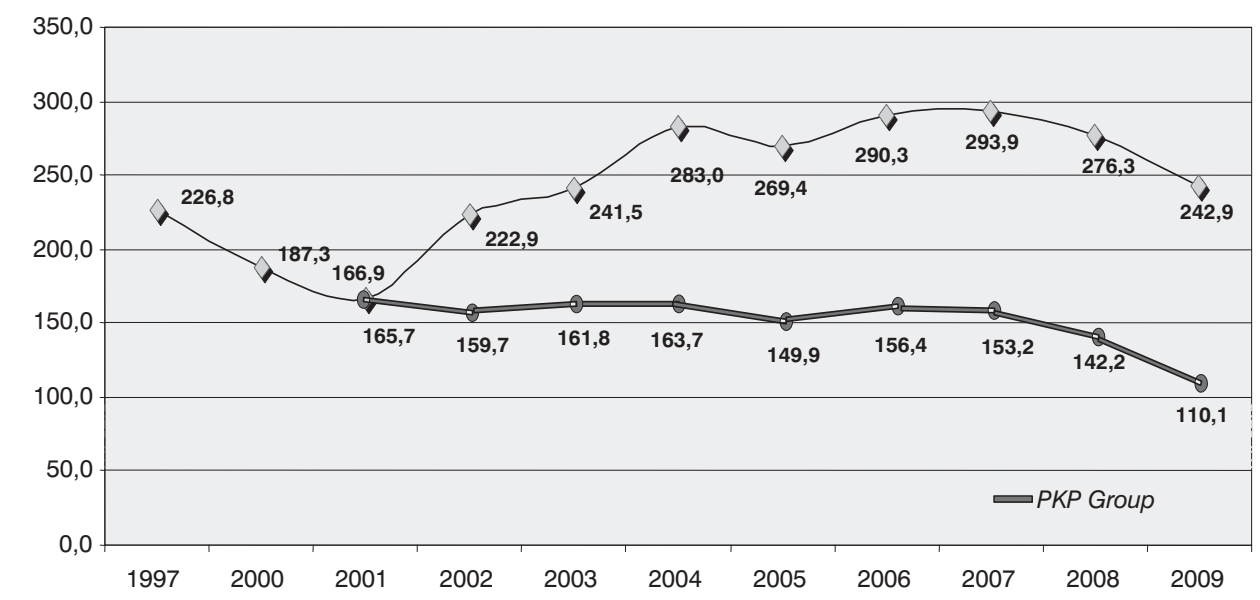

Source: UTK 
difference between their share in terms of transport volume (tonnes) and their share in terms of transport performance (tonnes $/ \mathrm{km}$ ), in clear favour of the former. This fact alone suggests a highly localized character of competition in the freight market in Poland over this period. For instance, for the year $2004-$ when Poland joined the EU - the transport volume share of the freight weight record-holders PTKiGK Zabrze and PTKiGK Rybnik was respectively 13.5 and 9.6 times greater than their transport performance share. It is possible to state on this basis that the average distance travelled by them was significantly lower than the average for the sector overall. Since those companies have bases in their home cities, the geographic range of their activities had to be relatively small. Indeed, they produced the bulk of their revenues (and continue to do so) from freight transport services provided to Silesian coal mines. PKP Cargo's persistent monopolistic position was confirmed in 2004 by the President of the Polish antitrust authority Urzad Ochrony Konkurencji $i$ Konsumenta (hereafter, UOKiK).

The legal basis for competition in the Polish railway industry was finally determined by a new law on railway transport adopted in 2003 (hereafter, the law on railway transport) and implementing provisions of the so-called first EU railway package of $2001^{8}$. It was the Act of 2003 that established the position of the President of the Urzad Transportu Kolejowego (Railway Transport Office; hereafter, UTK) and listed rail market regulation among the authority's primary tasks. The Polish railway market gained on this basis, at least formally, an independent regulator appointed and dismissed by the Prime Minister. The main market-regulatory task assigned to the UTK President was the supervision of the upstream market (i.e. infrastructure) - combating monopolistic practices in the downstream market (i.e. operations) was left to the UOKiK President, the regulator was obliged however to co-operate with the antitrust authority in this regard ${ }^{9}$.

The seemingly clear division of responsibilities between these two bodies of public administration was facilitated by the legal recognition of the vertical separation of railway infrastructure from rail transport operation, introduced

8 Directive 2001/12/EC of the European Parliament and of the Council of 26 February 2001 amending Council Directive 91/440/EEC on the development of the Community's railways, OJ [2001] L 75/1; Directive 2001/13/EC of the European Parliament and of the Council of 26 February 2001 amending Council Directive 95/18/EC on the licensing of railway undertakings, OJ [2001] L 75/26; Directive 2001/14/EC of the European Parliament and of the Council of 26 February 2001 on the allocation of railway infrastructure capacity and the levying of charges for the use of railway infrastructure and safety certification, OJ [2001] L 75/29.

${ }^{9}$ For upstream/downstream markets concept see e.g. O. Shy, Industrial organization: theory and applications, MIT Press 1996, or D. F. Spulber, Regulation and Markets, MIT Press 1989. 


\begin{tabular}{|c|c|c|c|c|c|c|c|c|c|c|c|c|c|}
\hline \multirow{6}{*}{\multicolumn{2}{|c|}{ 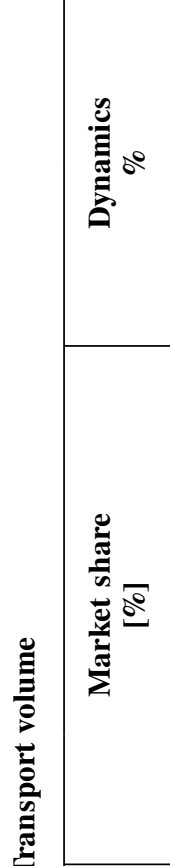 }} & \multirow{2}{*}{ 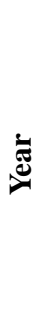 } & 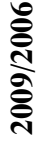 & $\begin{array}{l}\frac{0}{6} \\
0 \\
0 \\
1\end{array}$ & 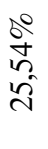 & \begin{tabular}{l}
$\stackrel{8}{\infty}$ \\
$\stackrel{2}{\pi}$ \\
\multirow{1}{1}{}
\end{tabular} & 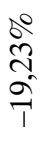 & $\begin{array}{l}\delta^{\circ} \\
\infty \\
\text { in } \\
\text { nీ }\end{array}$ & $\begin{array}{l}D^{0} \\
\text { dे } \\
\stackrel{2}{2}\end{array}$ & 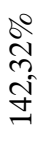 & $\begin{array}{l}\stackrel{0}{ } \\
\infty \\
\infty \\
\infty \\
\infty\end{array}$ & $\frac{\sqrt{0}}{\pi}$ & 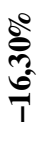 \\
\hline & & & 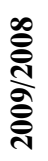 & \begin{tabular}{l}
$\infty$ \\
$\infty$ \\
$n$ \\
\multirow{1}{n}{} \\
$i$
\end{tabular} & $\begin{array}{l}\stackrel{0}{0} \\
\text { ल } \\
\stackrel{N}{N}\end{array}$ & $\begin{array}{l}\stackrel{0}{ } \\
\text { बे } \\
\hat{\varphi}\end{array}$ & $\begin{array}{l}0 \\
+0 \\
\infty \\
\infty \\
0\end{array}$ & $\begin{array}{l}\stackrel{0}{0} \\
0 \\
0 \\
0 \\
1\end{array}$ & 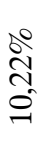 & $\begin{array}{l}J^{\circ} \\
\stackrel{+}{J} \\
\stackrel{-}{=}\end{array}$ & 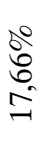 & $\begin{array}{l}\delta^{\circ} \\
\text { बू } \\
\text { an }\end{array}$ & 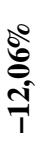 \\
\hline & & & ڤ્亏ે & 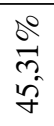 & $\begin{array}{l}\frac{2}{5} \\
\text { â }\end{array}$ & 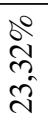 & \begin{tabular}{l}
$\stackrel{2}{2}$ \\
\multirow{2}{\approx}{}
\end{tabular} & $\begin{array}{l}\stackrel{8}{ } \\
\because \\
\end{array}$ & 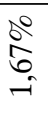 & $\begin{array}{l}\stackrel{d}{ } \\
\stackrel{a}{+} \\
\text { i }\end{array}$ & 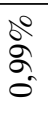 & $\begin{array}{l}0 \\
\infty \\
\infty \\
i n \\
\text { in }\end{array}$ & $\begin{array}{l}\text { 8̊ } \\
\text { छ̊ } \\
8\end{array}$ \\
\hline & & $\bar{\Xi}$ & $\stackrel{\infty}{\stackrel{\overbrace{}}{~}}$ & $\begin{array}{l}\frac{8}{\sim} \\
\stackrel{f}{\sigma}\end{array}$ & $\begin{array}{l}\stackrel{d}{ } \\
\check{\sigma} \\
\sigma\end{array}$ & 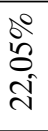 & $\begin{array}{l}\stackrel{8}{2} \\
\stackrel{2}{2} \\
=\end{array}$ & 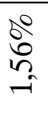 & $\begin{array}{l}\stackrel{D}{2} \\
\stackrel{m}{\sim}\end{array}$ & $\begin{array}{l}\overbrace{0}^{\circ} \\
\dot{\infty} \\
-\end{array}$ & 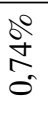 & $\begin{array}{l}\stackrel{8}{R} \\
\stackrel{f}{f} \\
+\end{array}$ & $\begin{array}{l}\text { 8̊ } \\
8 \\
8 \\
8\end{array}$ \\
\hline & & $\approx$ & હ্ণ & $\begin{array}{l}\frac{\delta}{n} \\
\text { त̂ } \\
\text { ñ }\end{array}$ & $\begin{array}{l}d^{0} \\
\text { in } \\
\text { in }\end{array}$ & $\begin{array}{l}\text { de } \\
\text { ป̂ } \\
\text { ป̂ }\end{array}$ & $\begin{array}{l}0 \\
\text { do } \\
\text { in }\end{array}$ & 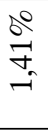 & $\begin{array}{l}\underbrace{\circ}_{0} \\
\text { ?n } \\
-1\end{array}$ & $\begin{array}{l}b_{0}^{\circ} \\
\text { ț } \\
-\end{array}$ & $\begin{array}{l}\overbrace{}^{0} \\
y^{n} \\
0\end{array}$ & $\begin{array}{l}b^{\circ} \\
\stackrel{2}{n} \\
\text { rn }\end{array}$ & 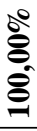 \\
\hline & & & ஓั & $\begin{array}{l}0 \\
\infty \\
\infty \\
\text { గn }\end{array}$ & $\begin{array}{l}d^{\circ} \\
\qquad \\
f \\
f\end{array}$ & 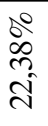 & 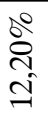 & 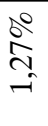 & 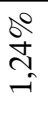 & $\begin{array}{l}\overbrace{}^{\circ} \\
\dot{0} \\
0 \\
0\end{array}$ & 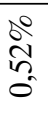 & $\begin{array}{l}\frac{\delta^{\circ}}{\partial} \\
\text { ल) }\end{array}$ & 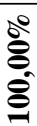 \\
\hline & & & & 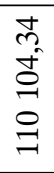 & $\begin{array}{l}\stackrel{\infty}{-1} \\
\underset{\sigma}{\sigma} \\
\sigma\end{array}$ & $\begin{array}{l}\infty \\
0 \\
\infty \\
0 \\
0 \\
0 \\
\wp\end{array}$ & 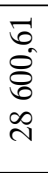 & $\begin{array}{c}\vec{\sigma} \\
\vec{\infty} \\
\infty\end{array}$ & 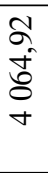 & $\begin{array}{l}0 \\
\stackrel{J}{f} \\
\stackrel{f}{0} \\
0\end{array}$ & 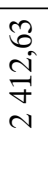 & 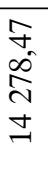 & 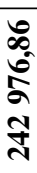 \\
\hline & 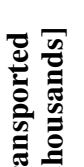 & $\bar{z}$ & 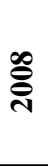 & $\begin{array}{l}\stackrel{N}{2} \\
\stackrel{-}{-} \\
\stackrel{N}{N} \\
\stackrel{J}{\sim}\end{array}$ & $\begin{array}{l}\text { శ్ } \\
\text { तु } \\
\text { m }\end{array}$ & 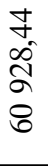 & $\begin{array}{l}\stackrel{R}{R} \\
\stackrel{+}{\pi} \\
\stackrel{n}{n}\end{array}$ & 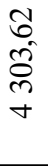 & $\begin{array}{l}\hat{0} \\
\infty \\
\infty \\
0 \\
m\end{array}$ & $\begin{array}{l}\stackrel{8}{+} \\
6 \\
\text { d } \\
\text { in }\end{array}$ & $\begin{array}{l}0 \\
+ \\
0 \\
2 \\
0 \\
\sim\end{array}$ & 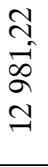 & 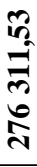 \\
\hline & 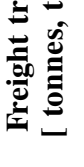 & $\gtrsim$ & હ్తి & $\begin{array}{l}\stackrel{2}{2} \\
\stackrel{2}{f} \\
\stackrel{2}{2} \\
\stackrel{2}{2}\end{array}$ & 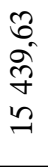 & 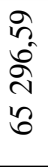 & 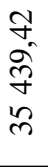 & $\begin{array}{l}\hat{\infty} \\
\hat{\delta} \\
\stackrel{0}{\sigma} \\
+\end{array}$ & 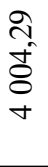 & 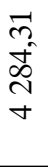 & \begin{tabular}{l} 
\pm \\
\multirow{\Delta}{n}{} \\
\end{tabular} & \begin{tabular}{l}
0 \\
\multirow{N}{\pm}{} \\
N \\
0
\end{tabular} & 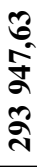 \\
\hline & & & ஓั & 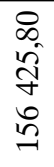 & 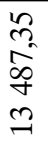 & 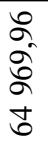 & 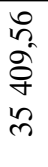 & 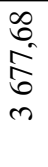 & 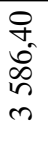 & $\begin{array}{l}\text { Ñ } \\
\dot{J} \\
\text { a } \\
\text { v }\end{array}$ & $\begin{array}{l}0 \\
0 \\
2 \\
n\end{array}$ & $\begin{array}{l}\dot{I} \\
0 \\
0 \\
+ \\
\infty\end{array}$ & 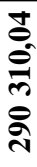 \\
\hline & 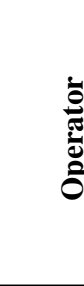 & & & $\begin{array}{l}\mathbf{0} \\
0 \\
0 \\
0 \\
2\end{array}$ & 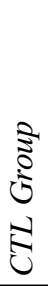 & 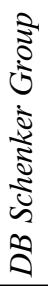 & 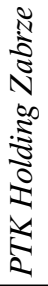 & 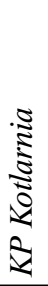 & 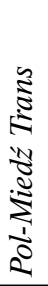 & 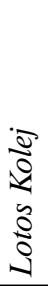 & 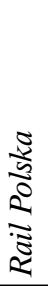 & $\frac{5}{3}$ & $\underset{\Xi}{\Xi}$ \\
\hline
\end{tabular}


earlier by the restructuring process of the PKP and the creation of PLK ${ }^{10}$. The law of 2003 introduced a ban, referred to in economics literature as a 'line of business restriction' 11 , preventing the infrastructure manager from acting on the downstream market ${ }^{12}$. Thus, while PLK remained part of the PKP Group, its actions came under the supervision of a specialized regulatory body. PLK was obliged to submit its network statement and charges list for approval, which made it to a large extent immune to any kind of pressure from the PKP holding company. As a result, access to the infrastructure managed by PLK no longer caused controversy - with the exception of the level of its access charges. Indeed, access charges remained much higher in Poland than in most other EU countries due to the low level of public funding available to rail infrastructure and the lack of any incentives for PLK to lower its costs.

In subsequent years, the market shares of private operators continued to grow to reach nearly 55\% of the transport volume at the end of 2009 (see Tab. 1). It is worth noting that their share in transport performance has also risen from less than $8 \%$ in 2004 to over 30\% in 2009 which is a sign of increasing competitive pressure exerted by private undertakings on the incumbent (see Tab. 2). It is also estimated that growing competition resulted in a gradual decline, of about $25 \%$, in the rates charged on the Polish rail freight market in the period between 2004 and 2008. The freight rates fell by another $20 \%$ in 2009 due to a price war caused by the economic crisis. Nonetheless, growing competition was accompanied by market consolidation and a number of takeovers undertaken by external players ${ }^{13}$. In 2009, freight services were provided in Poland by 40 railway operators.

However, the recent rapid development of competition in Polish rail freight was certainly not a result of the introduction of the non-discriminatory access to railway infrastructure, nor of the activities of the market regulator.

10 For detailed description of vertical separation concept in railway transport see, e.g., M. Król, 'Benefits and Costs of Vertical Separation in Network Industries. The Case of Railway Transport in the European Environment' (2009) 2(2) YARS.

11 See e.g. J.J. Laffont, J. Tirole, Competition in Telecommunications, MIT Press 2001.

12 There are derogations from this provision in the law on the basis of which integrated rail undertakings can operate in Poland i.e. PKP SKM and PKP LHS.

13 In 2007, PTKiGK Rybnik was taken over by PCC Rail and a 75\% share package of CTL Logistics was acquired by the British private equity fund Bridgepoint. In 2009, the German Deutsche Bahn acquired, by way of its daughter company DB Schenker, the logistics branch of PCC group (PCC Logistics), PCC Rail included. 


\begin{tabular}{|c|c|c|c|c|c|c|c|c|c|c|c|c|c|}
\hline \multirow{6}{*}{\multicolumn{2}{|c|}{ 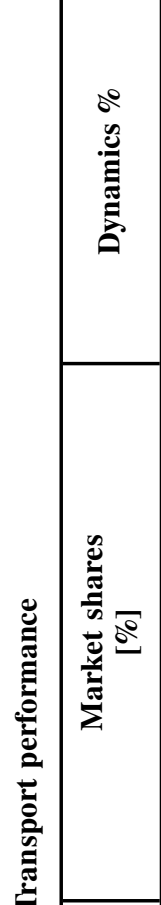 }} & \multirow{2}{*}{$\dot{\Xi}$} & 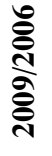 & 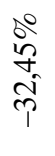 & 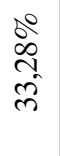 & 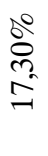 & $\begin{array}{l}\frac{8}{2} \\
\stackrel{2}{0} \\
i\end{array}$ & $\begin{array}{l}0^{\circ} \\
\text { m } \\
\stackrel{2}{7}\end{array}$ & 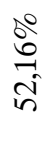 & 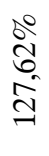 & 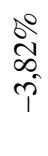 & 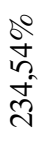 & $\frac{\infty}{\infty}$ \\
\hline & & & 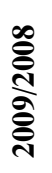 & 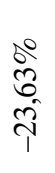 & $\begin{array}{l}\delta_{0}^{0} \\
\stackrel{0}{0} \\
\infty \\
0\end{array}$ & $\frac{d}{a}$ & $\begin{array}{l}\text { o̊ } \\
\text { No } \\
\text { d̂ } \\
7\end{array}$ & 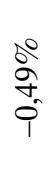 & $\begin{array}{l}\text { o̊ } \\
\text { oे } \\
\text { aे }\end{array}$ & $\begin{array}{l}\Xi^{0} \\
\stackrel{\infty}{0} \\
\exists \\
=\end{array}$ & $\begin{array}{l}\stackrel{0}{\circ} \\
\stackrel{+}{+} \\
=\end{array}$ & $\begin{array}{l}d^{0} \\
\infty \\
\\
\stackrel{y}{q}\end{array}$ & $\begin{array}{l}80 \\
\frac{8}{7} \\
\frac{10}{1}\end{array}$ \\
\hline & & \multirow{4}{*}{$\underset{\mathbb{J}}{\grave{\Xi}}$} & હે & $\begin{array}{l}D^{0} \\
0 \\
0 \\
\infty \\
0\end{array}$ & $\begin{array}{l}50 \\
8 \\
0 \\
\infty\end{array}$ & 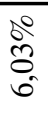 & $\begin{array}{l}8 \\
8 \\
0 \\
i\end{array}$ & $\begin{array}{l}\text { ठ̊ } \\
\text { ते } \\
\text { - }\end{array}$ & $\begin{array}{l}\frac{8}{2} \\
\stackrel{2}{n}\end{array}$ & $\begin{array}{l}\frac{8}{6} \\
6 \\
n\end{array}$ & 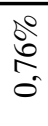 & $\begin{array}{l}\frac{d^{2}}{\sigma} \\
\text { in }\end{array}$ & $\begin{array}{l}\stackrel{0}{\circ} \\
\stackrel{8}{8} \\
\text { 。 }\end{array}$ \\
\hline & & & 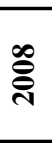 & $\begin{array}{l}\stackrel{0}{0} \\
\hat{0} \\
\hat{2}\end{array}$ & $\begin{array}{l}b^{0} \\
\infty \\
6 \\
6\end{array}$ & $\begin{array}{l}\frac{0}{6} \\
\text { in }\end{array}$ & $\begin{array}{l}\frac{0}{n} \\
i n \\
i\end{array}$ & $\begin{array}{l}\delta^{\circ} \\
\text { ñ } \\
0\end{array}$ & $\begin{array}{l}\frac{b}{0} \\
\hat{\sigma} \\
\hat{\sigma}\end{array}$ & $\begin{array}{l}\stackrel{\leftrightarrow}{ } \\
\stackrel{2}{2} \\
\stackrel{\nabla}{*}\end{array}$ & $\begin{array}{l}\delta^{0} \\
\infty \\
2 \\
0\end{array}$ & $\begin{array}{l}d_{0} \\
\stackrel{2}{n} \\
\end{array}$ & 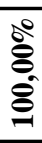 \\
\hline & & & હ) & 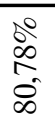 & 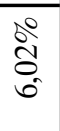 & 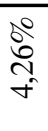 & $\begin{array}{l}b^{0} \\
\text { on } \\
i\end{array}$ & $\begin{array}{l}\frac{0}{n} \\
\tilde{\sigma}\end{array}$ & $\begin{array}{l}0 \\
0 \\
0 \\
0 \\
0\end{array}$ & $\begin{array}{l}b^{0} \\
2 \\
2 \\
\text { n) }\end{array}$ & $\begin{array}{l}\text { bo } \\
\text { ơ } \\
\text { d. }\end{array}$ & 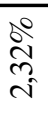 & $\begin{array}{l}\stackrel{8}{\circ} \\
8 \\
8 \\
8 \\
8\end{array}$ \\
\hline & & & ఫ્సి & $\begin{array}{l}\stackrel{d}{\partial} \\
\stackrel{\infty}{\circ}\end{array}$ & $\begin{array}{l}b 0 \\
m \\
2 \\
n\end{array}$ & $\begin{array}{l}\frac{\partial}{\pi} \\
\stackrel{7}{f}\end{array}$ & 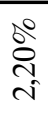 & 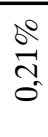 & $\begin{array}{l}\frac{8}{+} \\
\frac{8}{0}\end{array}$ & $\begin{array}{l}0^{0} \\
\text { d } \\
i\end{array}$ & $\begin{array}{l}0 \\
0 \\
0 \\
0 \\
0\end{array}$ & 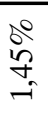 & 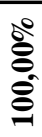 \\
\hline & \multirow{4}{*}{ 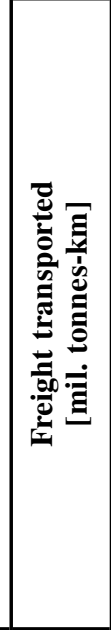 } & \multirow{4}{*}{ 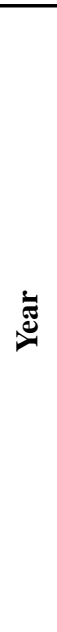 } & હ્ને & 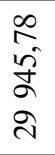 & $\begin{array}{l}\hat{a} \\
\hat{n} \\
\infty \\
n \\
n\end{array}$ & 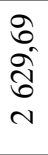 & $\begin{array}{l}\hat{a} \\
\vec{f} \\
\stackrel{2}{-}\end{array}$ & $\begin{array}{l}\circ \\
\stackrel{2}{0} \\
\text { ป̂ }\end{array}$ & $\begin{array}{l}\infty \\
\infty \\
0^{\circ} \\
\text { in }\end{array}$ & 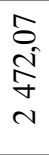 & $\begin{array}{c}\text { I } \\
\text { กิ } \\
\text { ले }\end{array}$ & \begin{tabular}{l}
$\hat{b}$ \\
$\qquad$ \\
\multirow{2}{n}{} \\
$\sim$
\end{tabular} & 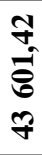 \\
\hline & & & 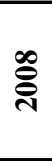 & 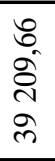 & $\begin{array}{l}m \\
\infty \\
\infty \\
\infty \\
m\end{array}$ & $\begin{array}{l}\exists \\
\exists \\
\infty \\
\infty \\
\sim\end{array}$ & $\begin{array}{l}\tilde{\sigma} \\
\stackrel{\Omega}{\Omega} \\
-1\end{array}$ & 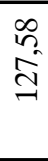 & $\begin{array}{l}\hat{\sigma} \\
\infty \\
o \\
\sigma\end{array}$ & 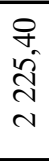 & $\begin{array}{l}\text { ले } \\
\text { ळे } \\
\text { ते }\end{array}$ & $\begin{array}{l}\tilde{f} \\
\tilde{\infty} \\
\tilde{\infty}\end{array}$ & $\begin{array}{l}\text { \%ू } \\
\hat{8} \\
\text { in } \\
\text { in }\end{array}$ \\
\hline & & & હ్ & 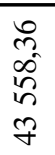 & $\begin{array}{l}\text { J } \\
\text { d } \\
\text { d } \\
m\end{array}$ & 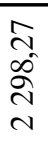 & 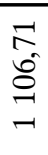 & $\begin{array}{l}\text { กิ } \\
\text { ปn }\end{array}$ & $\begin{array}{l}\text { ro } \\
\stackrel{6}{6}\end{array}$ & 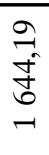 & $\begin{array}{l}\stackrel{0}{\circ} \\
\stackrel{0}{\sim}\end{array}$ & $\begin{array}{l}\infty \\
0 \\
0 \\
\check{n} \\
\\
-\end{array}$ & 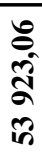 \\
\hline & & & ๕̊̀ & $\begin{array}{l}\stackrel{2}{7} \\
\vec{m} \\
\forall \\
\forall\end{array}$ & \begin{tabular}{l}
$\infty$ \\
$\infty$ \\
0 \\
\multirow{0}{0}{} \\
$\infty$ \\
$\sim$
\end{tabular} & 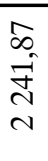 & $\begin{array}{l}\underset{7}{=} \\
= \\
=\end{array}$ & $\begin{array}{l}\text { d } \\
\text { I } \\
\text { }\end{array}$ & $\begin{array}{l}\text { స̂. } \\
\text { న̂ }\end{array}$ & $\begin{array}{l}8 \\
8 \\
8 \\
0 \\
0\end{array}$ & $\begin{array}{l}\bar{\sigma} \\
\tilde{n} \\
\text { mे }\end{array}$ & $\begin{array}{l}\vec{N} \\
\stackrel{2}{\Omega}\end{array}$ & 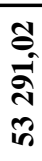 \\
\hline & 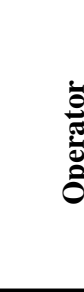 & & & $\begin{array}{l}8 \\
0 \\
0 \\
0 \\
0\end{array}$ & $\begin{array}{c}0 \\
0 \\
0 \\
0 \\
0 \\
0\end{array}$ & 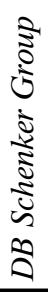 & 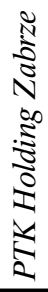 & 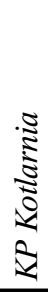 & 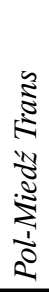 & 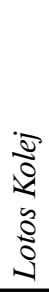 & 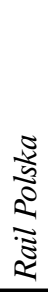 & $\frac{5}{5}$ & \\
\hline
\end{tabular}




\section{Troubles with access to railway infrastructure}

It should be stressed that the vertical separation of the former monopolist's railway network from its transport operations did not cover the entire Polish railway infrastructure. As a result of the restructuring of PKP, some sidings were left in the purview of the incumbent PKP Cargo which is under no obligation to make them available to other operators ${ }^{14}$. This situation results from an inappropriate implementation of EU provisions concerning the principle of 'non-discriminatory access to infrastructure'. According to Polish law, the only part of the network infrastructure which should be made available to other railway undertakings is that which remains at the disposal of the infrastructure manager. Railway companies are therefore entitled to 'non-discriminatory access' but not to the entire infrastructure. A railway undertaking that controls goods loading and unloading points is under no obligation to share them. This is an obvious breach of EU legislation.

What is more, Polish law has not considered railway sidings as part of the national railway infrastructure since 2007. Consequently, there is currently no obligation to make them accessible to others even though they constitute a necessary element of railway freight operations. This approach is not only in breach of EU rules and contradicts the very idea of liberalization, it also defies common sense.

It seems that the key reason for the failure to treat sidings as part of railway infrastructure was the government's desire to impose fees for the perpetual use of the land on which they are situated. An important fragment of the legal justification for this exclusion reads as follows: 'In accordance with Article 8 of the Law on railway transport, the land occupied by rail infrastructure is exempt from the fees for perpetual use, which means that businesses located on such land would not be subjected to such fees' 15 . The fee problem seemed to have made Polish lawmakers blind to the issue of competition on the railway market. This raises the question of the way the market regulator performs its duties while finding itself in such a gross violation of the principles of liberalization. This issue will be addressed in more detail later on in the discussion.

While PLK makes its sidings available (as do other infrastructure managers), the incumbent PKP Cargo eagerly takes advantage of the opportunity created

14 Approximately $1 / 3$ of the total number of sidings of the former monopolist (UTK unofficial information)

15 The justification of the governmental draft law changing the Act on Rail Transport and the Act on Environmental Protection (druk sejmowy nr 2013 z dnia 13 sierpnia 2007 r.). 
for it by the legislator to engage in vertical market foreclosure ${ }^{16}$ and strategic deterrence of potential market entrants. PKP Cargo routinely denies access to loading and unloading points that are under its control. It is worth quoting here, as a typical example, one of the statements given by the President of PKP Cargo in an interview for a renowned national newspaper: '[...] PKP CARGO SA has terminals, sidings [...], but this infrastructure is not widely available to all. It is the property of the company. And we have no obligation to provide access to this infrastructure on the basis that our competitors want us to [...]. [...] It is unacceptable to demand access to someone's property without taking into account the rights of the owner. And this is the way many private companies approach our terminals, sidings [...], usurping the right to access $^{\prime 17}$. This opinion is repeated in other official statements made by the representatives of PKP Cargo and its parent company (PKP SA). Moreover, the authors of the government's 'Strategy for Railway Transport till 2013' decided to make such actions even easier for the incumbent. They suggested that PKP Cargo should be granted 'property which constitutes production potential for the economic tasks of the operator in the areas of logistics and freight services, such as sidings, ramps, warehouses and logistics facilities ${ }^{\prime 18}$.

\section{Railway market regulator in Poland}

It seems justified to say that there is no real railway market regulator in Poland. The UTK President, appointed to perform this function, fails to do so. The authority's actions are limited to what can be described as 'politics of survival' or 'politics of failure to act'. In practice, the regulator focuses on the admittedly very important tasks relating to rail transport safety. While the supervision of railway infrastructure access remains its key responsibility in the field of market regulation, the authority's approval of the aforementioned method of infrastructure access regulation in Poland constitutes an instructive example of the regulator's passive approach.

16 The expression 'vertical market foreclosure' is used to refer to a situation where a company operating in a competitive downstream market simultaneously operates in a closely connected monopolistic upstream market and denies (or hinders) access to an asset (e.g. infrastructure) supplied by this market which is a key production input in the downstream market. For detailed economic description see, e.g., P. Rey, J. Tirole, A Primer on Foreclosure, IDEI, Toulouse 2006.

17 Interview with W. Szczepkowski, PKP CARGO S.A. Manging Director published [in:] Gazeta Prawna, 26 September 2007.

18 Strategy for Railway Transport till 2013, Warszawa 2007, p. 32. 
Many reasons have contributed to this situation, the most important of which seems to be the regulator's lack of independence from the Minister of Transport. Even though the UTK President is appointed by the Prime Minister, the latter acts on request submitted by the Minister. It is also the Minister that may ask the Prime Minister to dismiss the UTK President. Even so, Polish legislation does not contain an exhaustive list of the circumstances in which such a request can be made, nor does it specify the UTK President's terms of office indicating only that the regulator is supervised by the Minister of Transport. As a result, the latter is not only entitled to nominate the candidates for the UTK President but also able to exert pressure on the regulator. Needless to say, the appointment and dismissal of the two UTK Vice-Presidents remain at the sole discretion of the Minister. Consequently, the railway transport office is in practice treated as, and performs the function of one of the departments of the ministry responsible for transport matters, carrying out the tasks of market-regulation in a manner consistent with the policy pursued by successive ministers (or, in practice, their deputies responsible for rail transport).

The ministry of transport was and remains, to quote one of the experts, 'a ministry of state transport companies'19. Its priority has been the improvement of the financial condition of the PKP Group and, with respect to the railway freight market, the strengthening of the position of PKP Cargo as a 'national operator' with 'a significant share in the market' ${ }^{20}$. Since PKP Cargo continues to rapidly lose its position, the ministry and consequently also the UTK President tends to turn a blind eye to its anti-competitive practices and the flawed institutional and legal framework of the Polish railway transport market. The incumbent is thus encouraged to block the development of competition. It is worth stressing also that it is the Minister of Transport that exercises proprietary functions in relation to the PKP Group.

As it can be seen from the above, there is a fundamental conflict between the government's regulatory, proprietary and economic functions with respect to the railway freight market. Another conflict, relating this time to the UTK itself, is associated with its dependence on the members of the PKP Group. There are two dimensions to this conflict. First, PKP executives exert pressure on the regulator to make the authority issue administrative decisions favorable to their interests, taking advantage of the fact that the Minister of Transport that oversees their activities is at the same time the superior of the UTK President. Second, it is not uncommon for senior UTK officials, directly

19 W. Rydzkowski, 'Czy kolej wie, dokąd zmierza?' (2006) 3 Rynek Kolejowy.

${ }^{20}$ Such objectives are formulated in the Strategy for Railway Transport till 2013 (p. 31, 32). 
responsible for the administrative decision-making process, to be connected with the entities subject to those decisions ${ }^{21}$.

The UTK President's 'politics of failure to act' in the area of market regulation can be attributed to other factors also, besides the authority's lack of independence. Until recently, both the UTK President and its senior officials were appointed from the so-called 'state human resources' list which greatly limited the circle of eligible candidates. The appointment procedure failed to guarantee an appropriate level of expertise, nor did it ensure impartiality (absence of a conflict of interests) and market awareness. Relevant in this context is also the very modest staffing (about 15-20 people including the UTK Vice-President and the director of the department) of the market-regulation division of the UTK and the fact that the knowledge and experience of its employees leaves a lot to be desired.

The 'politics of failure to act' means that the UTK President does not take any actions to amend the defective institutional and legal framework of the Polish railway market. Not to mention, the railway authority fails to encourage the government to consistently liberalize another markets subjected to its supervision (i.e. passenger rail services), which is the mission of every active regulator. The UTK President fails also to co-operate with the antitrust authority in preventing monopolistic practices in the downstream market. Only once has a decision on railway infrastructure access been issued by the regulator ex officio, its work is rated very low by the market and it would be an understatement to say that it has developed very little in terms of public authority within the sector.

\section{Conclusions}

The regulation of the rail freight market in Poland is 'producer protection' focused even though its only beneficiary is the incumbent PKP Cargo. Lower prices and higher service quality, resulting from growing competition have so far seemed to be of no value to the public authorities. It even seems justifiable to suggest that regulatory policy has often been implemented in such a way as to impede new firms from entering the market and reduce the growth rate of those that managed to do so already - exactly the situation that was once described by G.J. Stigler in his renowned and controversial economic theory of regulation ${ }^{22}$.

${ }^{21}$ In extreme cases, they were the employees of railway companies send on unpaid leave for the duration of their employment in the UTK.

22 G. J. Stigler, The Theory of Economic Regulation (1971) 2(1) Bell Journal of Economics and Management Sciences. 
For example, in order to start operating in the rail freight market in Poland, one is obliged by the railway transport law of 2003 to obtain a license that confirms that company's ability to perform the functions of a railway undertaking. An applicant is required to meet specific criteria to acquire a license - the UTK President cannot refuse to grant it if these are met. Still, the regulator refused to grant a license to Connex Polish Railways Sp. Ltd. (a subsidiary of one of the largest transport companies operating on European markets - Veoila Transport) referring to the vagueness of the applicant's declaration concerning its equipment with railway vehicles including locomotives and wagons. The refusal was issued despite the fact that details of such declarations are neither specified by Polish legislation nor by EU law. This highly controversial decision of the UTK President effectively prevented Connex from entering the Polish rail freight market ${ }^{23}$.

Despite this, until the onset of the global financial crisis, the rail freight business in Poland was consistently expanding thanks to the growth of new market players. This fact may show correctness of the decision to introduce competition (both for the market and in the market) on rail markets characterized by well-developed infrastructure and significant demand for transport of bulk commodities and containers. But there is of course always a way to do it 'better'.

In the case of the Polish rail freight market, the 'better way' should come down to the urgent implementation of the following recommendations:

- Reintroduce sidings into the catalogue of railway infrastructure;

- Make the obligation to grant access to railway infrastructure applicable regardless of who it belongs to;

- Transfer the entire infrastructure of the former state monopoly PKP to the infrastructure manager PLK (i.e. extend vertical separation to the entire core railway infrastructure);

- Demerge the PLK company from the PKP Group (i.e. strengthen vertical separation with the separation of ownership);

- Ensure the independence of the regulatory authority both from the Minister of Transport and from those subject to regulation (at least introduce a set term of office for the UTK President and a legally binding list of causes for dismissal by the Prime Minister);

23 Another highly controversial matter which gained a lot of publicity among market participants was connected with the obligation to acquire a document certifying the right of a vehicle to move on the railway infrastructure - a license for the exploitation of a type of railway vehicle. The UTK President issued such documents for Freightliner PL locomotives at first but then suddenly withdrew the decision, making it impossible for the company to start operations and exposing them to a capital freeze in the very capital-intensive means of production (traction vehicles). 
- Equip the authority with regulatory tools appropriate for the upstream market ${ }^{24}$ as well as with the human resources necessary to carry out its mission;

- Considered might also be the separation of the UTK's regulatory department from the its overall structure and the creation, on its basis, of a regulatory office which could start building its authority in the industry from scratch; in such case, the UTK would remain the 'rail office' responsible for security and the supervision of traffic.

If the planned privatization of the incumbent PKP Cargo takes place, it will probably be more profitable to this company than the protection against competition in the market. It will also entail the elimination of the conflict between the proprietary and regulatory functions of the public authority in the downstream market, which will be conducive to a further development of the latter.

\section{Literature}

Grobelny M., 'Pięć lat wolnego rynku kolejowych przewozów towarowych w Polsce' ['Five years of free cargo rail transport in Poland'] (2008) 9 Rynek Kolejowy.

Interview with W.Szczepkowski, PKP CARGO S.A. Manging Director, Gazeta Prawna, 26 September 2007.

Justification of the governmental draft law changing the Act on Rail Transport and the Act on Environmental Protection (druk sejmowy nr 2013 z dnia 13 sierpnia 2007 r.).

Król M., 'Benefits and Costs of Vertical Separation in Network Industries. The Case of Railway Transport in the European Environment' (2009) 2(2) YARS.

Laffont J.J., Tirole J., Competition in Telecommunications, MIT Press 2001.

Rey P., Tirole J., A Primer on Foreclosure, IDEI, Toulouse 2006.

Rydzkowski W., 'Czy kolej wie, dokąd zmierza?' ['Does a rail knows where it goes?'], (2006) 3 Rynek Kolejowy.

Shy O., Industrial organization: theory and applications, MIT Press 1996.

Spulber D. F., Regulation and Markets, MIT Press 1989.

Stigler G. J., 'The Theory of Economic Regulation' (1971) 2(1) Bell Journal of Economics and Management Sciences.

Stigler G.J., Friedland C., 'What can regulators regulate? The case of electricity' (1962) $\mathrm{V}$ The Journal of Law and Economics.

Strategy for Railway Transport till 2013, Warszawa 2007.

${ }^{24}$ Under the current provisions, one of the tasks of the UTK President is to 'approve and coordinate the charges for using the allocated paths of trains in the terms of compliance with the principles of determining these charges'. There is nothing there however, to motivate PLK to keep its operational costs at a reasonable level. In particular, the UTK president cannot refuse to approve infrastructure access charges because of their excessive increase compared to the past. PLK has the right to take into account all of its costs when determining the charges. As a result, the UTK President is more of a supervisor of PLK than a market regulator. 